\title{
«How to have healthy children». Responses to the falling birth rate in Norway, c. 1900-1940
}

\author{
Ida Blom \\ Department of Archeology, History, Culture and Religion. University of Bergen. Norway \\ ida.blom@hi.uib.no
}

Dynamis

[0211-9536] 2008; 28: 151-174
Fecha de recepción: 26 de septiembre de 2007

Fecha de aceptación: 13 de febrero de 2008

SUMMARY: 1.-Legislation supporting mothers. 2.-Control clinics for mothers and infants. 3.-Low attendance, reduced breast feeding, reduced infant mortality. 4.- - Hygienic mothers' clinics - (Mødrehygienekontorer). 5.-Discussing fertility and infant health. 6.-Sterilisation: Part of welfare policies? 7.-Conclusion.

ABSTRACT: This paper focuses on initiatives to improve infant health, as they developed in Norway especially during the interwar period. Falling birth rates were felt as a menace to the survival of the nation and specific initiatives were taken to oppose it. But crises engendered by the reduction in fertility strengthened opportunities for introducing policies to help the fewer children born survive and grow up to become healthy citizens. Legislation supporting mothers started in 1892 increased in the interwar years including economic features. Healthy mother and baby stations and hygienic clinics, aimed at controlling births were developed by voluntary organisations inspired from France and England respectively. A sterilization law (1934) paralleled some German policies.

PALABRAS CLAVE: Salud maternoinfantil, consultorios de lactantes, esterilización, Noruega.

KEYWORDS: Mother health, infant health, health stations, sterilization, Norway.

In 1921 the Norwegian feminist, Katti Anker Møller, published a leaflet with the title «A letter to Hard-Working Mothers on How to Have Healthy Children and Avoid Weakening Pregnancies» ${ }^{1}$. Her further initiatives soon became one of a number of policies to both improve infant health and limit the number of births. Her work was part of the growing interest in

1. Mohr, Tove. Katti Anker Møller - en banebryter. Oslo: Tiden Norsk Forlag; 1976 (1968), p. 196 197. 
infant care, from the last decades of the nineteenth century stimulated by the falling birth rate. Increasingly, in Norway as in most of Western Europe the reduced fertility was seen as a crisis that worried politicians and the medical profession, and policies were introduced to influence both the quantity and the quality of children ${ }^{2}$. This paper will focus on initiatives to improve infant health, as they developed in Norway from the turn of the century, but especially during the interwar period.

Responses to the crisis varied from one nation to the other. Pro-natalism was especially strong in France where the birth rate started falling earlier than in any other European country and continued to fall during the interwar period ${ }^{3}$. Anti-natalist propaganda was prohibited in 1920 and enforcement of penalties for abortion became stricter. Motherhood was encouraged by creating the fete des meres and medals were awarded to mothers with five or more children. During the 1930's generous family allowances, augmenting by number of children, were introduced. In Mussolini's Italy a rising birth rate was promoted as a result of national virility (virilita nazionale) and a foundation for the future Italian empire. Taxation fell more heavily on unmarried than on married men and state funded allowances for the wife and for dependant children as well as birth premiums were granted to fathers.

From 1915 all German mothers received an eight weeks maternity allowance, and during the Weimar Republic clinics were opened giving advice on contraception. But this liberal policy, focussing more on the quality than on the quantity of children, was immediately reversed with the victory of the Nazi regime. Marriage loans were initiated in 1933 and monthly child allowances were paid to fathers. In the hope of increasing fertility marriage was encouraged by levying taxes more heavily on unmarried than on married men. To prevent the birth of 'inferior' children, some fathers, mainly Jews, were excluded from all these provisions. The law on sterilisation the

2. Schiøtz, Aina. Folkets helse - landets styrke. 1850-2003. Det offentlige helsevesen iNorge 1603-2003. Vol. 2. Oslo: Universitetsforlaget; 2003, p. 239. On the development of Norwegian fertility c. 1900 to 1960 see Dyrvik, Ståle; O'Neill, C. J. Norges Befolkning. Oslo: J.W. Cappelens Forlag as.; 1975, p. 23-26, and Dyrvik, Ståle. Den demografiske overgangen. Oslo: Det norske Samlaget; 2004.

3. Where no other sources are cited, the following builds on Bock, Gisela. Women in European history. Oxford and Maiden: Blackwell Publishers; 2002, p. 181-189 and 206-218. Mclaren, Angus. A history of contraception. From Antiquity to the present day. Oxford: Blackwell Publishing; 1990, p. 162-169, 189-192, and 215-244. 
same year was used to prevent the birth of individuals deemed mentally or eugenically inferior.

British policies were centred on assisting mothers to take care of their infants. Also in Britain abortion continued to be criminalised, but during the 1920's information and advice on contraception became more easily available. The Maternal and Child Welfare Act from 1918 furthered municipal infant welfare centres and health visitors. Antenatal and postnatal clinics were gradually established to assist mothers. From 1911 women married to men who were members of the National Insurance scheme received maternity benefits ${ }^{4}$. But decades of discussions on the principles of family allowances only in 1945 led to state-funded child allowances from the birth of the second child. Protests from women both within and without Parliament succeeded in making this allowance payable to the mother, not as originally intended to the father.

How did Norwegian policies fit into this spectre of responses to the falling birth rate?

Also in Norway the fertility decline accelerated during the interwar period. Between 1910 and 1930 the number of children born per 1000 married women aged 15-49 was almost halved (Table 1).

Table 1. Marital fertility rates in Norway, 1889-1962

\begin{tabular}{lc}
\hline & Births per 1000 married women (per year) \\
\hline $1889-92$ & 5,9 \\
$1910-11$ & 5,0 \\
$1930-31$ & 2,9 \\
$1946-47$ & 3,2 \\
$1959-62$ & 2,2 \\
\hline
\end{tabular}

Source: Dyrvik, Ståle; O'Neill, C.J. Norges Befolkning. Oslo: J.W. Cappelens Forlag as.; 1975, p. 24.

Urban communities, especially Oslo, pioneered this trend. After a sharp decline between 1900 and 1910 the marital fertility rate was even more seriously reduced during the following decades. The reduction started a little

4. D'Cruze, Schani. Women and the family. In: Pervis, June, ed. Women's History: Britain, 1850-1945. London: UCL Press Limited; 1995, p. 55-60. 
earlier in the western middle class part of the city and from a somewhat lower level than in the eastern working class quarters ${ }^{5}$.

Worries over morality, not over population developments, led to statutory provisions legislated as early as in 1889 and 1891 to stop promotion of contraception. Nevertheless, from around the First World War advertising of contraceptives augmented, and in 1927 a law court decision legalised the spread of information on contraception. Abortion on the other hand continued until 1960 to be penalised by years of imprisonment. All through the interwar period parliamentary discussions concerning this legislation continued to focus mainly on considerations of morality. There was no discussion of the problem of a possible reduction of the quantity of the population. But since the birth rate fell earlier and more pronounced with middle class families than with working class families, worries over the quality of the population soon surfaced ${ }^{6}$. The crises engendered by the reduction in fertility strengthened opportunities for introducing policies to help the fewer children born survive and grow up to become healthy citizens.

A great number of different circumstances were decisive for infant health. Three overlapping spheres of influence have been suggested: the mother or maternal environment, the home environment and the public environment ${ }^{7}$. I shall first sketch public policies intended to influence the home and maternal environment, then concentrate on three different approaches focussed especially on the maternal environment. Two of these approaches were launched by voluntary organisations and inspired from France and England respectively, the third was a law paralleling part of German policies.

5. Blom, Ida. Barnebegrensning - synd eller sunn fornuft? Bergen: Universitetsforlaget; 1980, p. 23-37. See also a translated and updated version of part of this book Blom, Ida. «Master of your own body and what is in it». Reducing marital fertility in Norway, 1890-1940. In: Janssens, Angelique, ed. Gendering the fertility decline in the Western World. Bern: Peter Lang; 2007, p. 59-84.

6. Blom, 1980, n. 5, p. 171-195 and 223-251.

7. Hubbard, William H. Infant Mortality in Scottish and Norwegian towns, c. 1860-1940. In: Andresen, Astri; Elvbakken, Kari Tove; Hubbard, William H., eds. Publich health and preventive medicine 1800-2000. Bergen: Stein Rokkan Centre for Social Studies \& Unifob As; 2004, p. 27-47 (30). 


\section{Legislation supporting mothers}

Like in Britain, Norwegian public policies were mainly concerned about infant health. Infant mortality was especially high with single mothers. This observation in 1892 resulted in a law that stressed the economic responsibility of fathers. The idea was to help unmarried mothers refrain from gainful employment and use time on infant care. It proved hard to enforce these provisions, but a group of laws, the Castberg Children's Laws, enacted in 1915 improved the lot of single mothers and their infants. In a number of ways this group of laws gave illegitimate children rights similar to those of children born in wedlock. Most importantly, they offered single mothers economic assistance during the first months of an infant's life. This was seen more as part of social policies than of population policies, since children born out of wedlock were only a small part of all children ${ }^{8}$. Other strategies were needed to reach wider circles.

National legislation already in 1892 prohibited women from working in factories the first months after giving birth ${ }^{9}$. But since mothers were not offered any financial compensation for loss of income, it may be assumed that this was of little help. It was only in 1911 that the law on sickness insurance offered mothers economic assistance for six weeks surrounding the arrival of a baby, on condition that the mother had been insured at least ten months before giving birth. Obviously, the idea was to avoid that women finding themselves pregnant would rush to be insured. Since insurance was offered only to people with paid work, most married mothers would not have this assistance. From 1915 the so called «mothers' insurance» offered wives whose husbands had sickness insurance free assistance from a midwife and some economic support to cover expenses involved in the birth of a child. More rest and better assistance to women who had given

8. Bjørnson, Øyvind; Haavet, Inger Elisabeth. Langsomt ble landet et velferdssamfunn. Trygdens historie 1894-1994. Oslo: Ad Notam Gyldendal; 1994, p. 109-122. Haavet, Inger Elisabeth. Milk, mothers and marriage. Family policy formation in Norway and its neighbouring countries in the twentieth century. In: Christiansen, Niels Finn et al. The Nordic model of welfare. A historical reappraisal. Copenhagen: Museum Tusculanum Press-University of Copenhagen; 2006, p. 189-214.

9. Bjørnson; Haavet, n. 8, p. 125-135. Seip, Anne-Lise. Veiene til velferdsstaten. Norsk sosialpolitikk 1920-75. Oslo: Gyldendal norsk forlag; 1994, p. 100-103. Blom, Ida. Kommunal omsorg for mødre og småbarn i Bergen i første halvdel av 1900-tallet. In: Nagel, Anne Hilde, ed. Velferdskommunen. Kommunenes rolle i utviklingen av velferedsstaten. Bergen: Alma Mater forlag; 1991, p. 61-88. 
birth was seen both as a means to avoid weakening the mother and as provisions against infant mortality. Worries over infant health were important motives for these provisions. Considerations of the size of the population were almost absent, but may be found in the comments of the parliamentary commission that in 1913 proposed the bill on the mothers' insurance. The commission stressed that it was important to give the family and marriage «the best possible economic foundation with a view to the quantity and the quality of the population» ${ }^{10}$. From 1920 municipal assistance to widowed and unmarried mothers was adopted in the capital and in some other municipalities, and finally, in 1936 working mothers became entitled to three months maternity leave with sickness benefits. Although at the time only a small percentage of married women were economically active, these policies may have assisted mothers in taking care of infants. A vivid discussion of adopting family allowances that would also reach mothers working only in the home started when the 1930 census confirmed the drastic reduction in marital fertility. Improving the family economy was seen as a means both to encourage marriage and to improve infant health. But the economic uncertainty of the 1930's and the Second World War prevented the adoption of family allowances until 1946.

These policies no doubt improved the home environment and assisted some mothers in taking care of their infants. But other initiatives aimed at improving infant health by influencing directly on the maternal environment, and such approaches proliferated during the interwar period. Building on annual reports from municipal health authorities and from two different kinds of clinics I shall outline two different responses to the crises of the falling birth rate. A collection of letters written to one of these clinics during the 1920's and a number of women's journals are used to find out how recommendations as to infant care were received by the mothers ${ }^{11}$.

10. Parliamentary document Ot.prp.nr. 35-1913, p. 30. See also Blom, Ida. Barselkvinnen mellom befolkningspolitik, sosialpolitikk og kvinnepolitikk fra 1880-årene til 1940. Historisk tidskrift. 1982, 61 (2): 141-161.

11. For a full analysis of around 4000 letters to this clinic, see Blom, 1980, n. 5, p. 64-154, and Blom, 2007, n. 5. 


\section{Clinics for mothers and infants}

One line of action was a new and energetic follow-up of traditional policies to encourage mothers to breastfeed more. Books and pamphlets attempting to convince mothers to prefer breastfeeding to other ways of feeding their infants have appeared in Europe since the early 18th century, in Denmark/ Norway since the 1760 's. The intension was to reduce infant mortality, partly as a means in mercantilist policies to increase the size of the population, but also in order to promote infant health ${ }^{12}$. Information on the importance of mothers' milk for the health of an infant was spread through journals and sometimes through midwives. From the early 20th century renewed efforts were made in this respect, expanding vividly during the interwar years. The medical profession and several voluntary organisations made great efforts to assist mothers in the care of infants. The crisis occasioned by the falling birth rate was used as a possibility to assist mothers to take better care of their infants.

The first maternal clinic was established in 1906 at the lying-in hospital in Oslo, the capital. Inspiration was found with practices introduced in the 1890's by the French obstetrician Pierre Budin, who founded the consultation des nourrissons at the Charite Hospital in Paris. Following Budin's ideas breast-feeding was promoted as the very best way to improve infant health. But Budin wanted mothers to be taught how to breastfeed according to the medical understanding of the best practice. That meant breast-feeding regularly at three hours interval, no more, no less. He stressed that it was dangerous to let the child have too much milk, since that would lead to digestive problems. He regarded breast-feeding as a natural process that any mother could perform and did not accept mothers' worries over problems with breastfeeding ${ }^{13}$. To keep alive the fewer children born was an important goal.

The maternal clinic in Oslo adhered to this policy. Mothers who had given birth at the lying-in hospital were strongly advised to consult the maternal clinic once a week to have the baby weighed, measured and checked

12. Moseng, Ole Georg. Ansvaret for undersåttenes helse 1603-1850. Oslo: Universitetsforlaget; 2003, p. 136-140. Torvaldsen, Gunnar. Infant mortality in the Nordic countries 1780-1820. In: Andresen; Elvbakken; Hubbard, n. 7, p. 49-65.

13. Norsk Magazin for Lægevidenskaben 1914, p. 326-332. 
for possible health problems. According to the doctors who had started this clinic, this worked excellently. But attendance was not as good as expected. In order to encourage mothers to come to the clinic the mothers who had the best cared-for infants were presented with a silver badge marked «FS»- Fødselsstiftelsen, (the Lying in Hospital). Despite this effort, predating the French and German policies of rewarding mothers with medals, for some years the clinic was closed because of low attendance. But in 1911 a new clinic was started, aiming at educating mothers to breastfeed in order to have healthy children ${ }^{14}$.

A similar clinic was opened in the second-largest city, Bergen, in 1910, following the same regime as the one in Oslo. Dr. Looft who was the driving force behind this clinic had made a survey of 1404 Bergen mothers and found that about half of these mothers breastfed for less than 6 months. They had stopped because - as they said - they did not have enough milk or they had themselves fallen ill. Looft wanted to persuade mothers to continue breastfeeding at least for a full year and follow Budin's regime feeding the child regularly every three hours. Attendance at this clinic for the first decade was also low, but the Bergen clinic survived. At the end of the 1920's mothers started crowding in to consult the clinic ${ }^{15}$. Gradually, more clinics were opened. By 1940 Bergen had four maternal clinics.

Several voluntary organisations engaged in these efforts. In Oslo the parish health association (Kristiania menighetspleie) in 1911 opened a «child care station» (barnepleiestasjon). Urban municipalities also opened health stations or control stations as they were often called. In 1930 the health of around $60 \%$ of the new born children in the capital were controlled at such clinics ${ }^{16}$. From 1914 also the Norwegian Women's Sanitary Association, (Norske kvinners sanitetsforening), an all-female voluntary association founded in 1896 and since 1900 very active in the fight against tuberculosis, opened what was called 'control stations for mothers and infants.' During

14. Schiøtz, n. 2, p. 104-109. Martinsen, Kari. Legers intersse for svangersakpet-en del av den perinatale omsorg. Tidsrommet ca. 1890-1940. Utrykkt manus 1986.

15. Blom, Ida. Smaa barn som prøveklut for al skens gammeldags husraad...? Konflikt om ammerutiner i Bergen 1910-1940. In: Norlid et al., eds. Över gränser. Festskrift til Birgitta Oden. Lund: Nordensttedtska stiftelsen; 1987, p. 41-64. Schiøtz, n. 2, p. 244.

16. See Martinsen, Kari. Omsorg, sykepleie, medisin. Historisk-filosofiske essays. Oslo: Tano As; 1989, p. 182-206 for a broad introduction to the approach of the medical profession to infant health. Schiøtz, n. 2, p. 109 and p. 244. 
the interwar period such clinics spread all over the country. In 1946 the Norwegian Women's Sanitary Association ran 270 control stations where mothers were taught infant care. Another 130 were mainly run by other private initiatives. They all stressed breastfeeding, but also gave advice on clothing, sleep and other problems pertaining to infant care. Most of the work was done by nurses, but doctors also attended some of the clinics. The atmosphere has been described as warm and helpful, but the silence that was said to fall over all the attendants at the arrival of the doctor reveals that the medical profession was met with special respect ${ }^{17}$.

In some of the bigger cities also other initiatives were taken to combat infant mortality. Charitable organisations started 'the Milk Drop', also following a French initiative, the 'gouttes de lait'. Mothers were admonished to breastfeed for at least 8-9 months, but where this was impossible milk was distributed free to poor families with children under 3 years of age. Families threatened by tuberculosis were given priority. Reports from municipal health authorities stated that these children were «regularly checked by the health inspector for their general health condition, their appearance, weight and care. Conditions in the homes were also submitted to control by the ladies of the committee», i.e. the charitable women who organised «the Milk Drop» ${ }^{18}$. Public help was followed by public control.

It seems that these initiatives in the beginning helped increase the number of mothers who breastfed for at least six months. But during the 1920's and 1930's - in fact until the late 1960's - statistics from the control clinics as well as from maternity wards revealed a decrease in the percentage of infants breastfed. This tendency manifested itself all over the country, and continued until the 1960 's ${ }^{19}$. Surprisingly, also, while breastfeeding

17. Schram, Constance Wiel. Norske Kvinners Sanitetsforening. Tiden og menneskne som skapte den. Vekst og virke i femti år. 1896-1946. Oslo: Norske Kvinners Sanitetsforenings Hovedstyre; 1946, p. 197-205. Schiøtz, n. 2, p. 244-245.

18. Brandt, Kristian. Spædbarns vegtøkning ved brysternæring. Norsk Magazin for Lægevidenskaben; 1927: 1123- 1124. Annual reports from the Bergen municipal Board of Health, printed in Sundhetstilstanden og Medicinalforholdene i Norge, 1927, p. 78; 1928, p. 78; and 1929, p. 82. Between 1930 and 1940 these reports are no longer printed in the national reports on health, but only found in the municipal reports, (Sundhetsvæsenets aarsberetninger) 1930 , p. $24 ; 1931$, p. $24 ; 1932$, p. $20 ; 1933$, p. $19 ; 1934$, p. $28 ; 1935$, p. $25 ; 1936$, p. $21 ; 1938$, p. 14.

19. Rosenberg, Margit. On the relation between living conditions and variables linked to reproduction in Norway 1860-1984. Oslo: Department of Informatics, University of Oslo; 1991, p. 45-58. Sources for Rosenberg's article are observations at the lying-in hospitals in the three 
was reduced, infant mortality continued to fall all during the interwar and early post war period (Table 2 ).

Table 2. Deaths under one year of age per 1000 live births, Norway, 1866-1963

\begin{tabular}{cccccc}
\hline & $1866-70$ & $1891-95$ & $1921-25$ & $1941-45$ & $1956-60$ \\
\hline Rate & 113,5 & 97.6 & 51,7 & 37,3 & 19,9 \\
\hline
\end{tabular}

Source: Dyrvik, Ståle; O’Neill, C.J. Norges Befolkning. Oslo: J.W. Cappelens Forlag as.; 1975, p. 18.

This poses three interesting questions. First, why would only a minority of mothers consult the early clinics? Second, why would breastfeeding be reduced despite the efforts of the increasing number of clinics? And third, why would infant mortality be reduced even as breastfeeding was also reduced?

\section{Low attendance, reduced breast feeding, reduced infant mortality}

Discussions in women's journals indicate that the low attendance at the early clinics might have a number of explanations. First, it would take time for a new institution to be known and accepted. But other circumstances may also have been important. One might be the competition between physicians and midwives. Midwives considered themselves - and were by many mothers considered - the real experts on infant care, but, especially in the beginning, physicians were reluctant to give midwives a say in consultations. Consequently, midwives may not have recommended mothers to contact the clinics ${ }^{20}$.

Some mothers protested the stiff-legged regime set up for them at the clinics. They maintained that a young baby would need food more often than at three hours interval. Some also insisted that breastfeeding was not

main cities of Bergen, Oslo and Trondheim. Until the Second World War many middle- and upper class women gave birth in their own homes. Consequently, they are not included in Rosenberg's material. Since they were the most likely to breastfeed for only a short period, the reduction in breastfeeding at the national level may have started earlier than indicated in Rosenberg's article.

20. Blom, n. 15, p. 53-54. Schiøtz, n. 2, p. 472-477. 
like the easy and natural process described by physicians. It could be a painful and difficult business ${ }^{21}$.

Finally, mothers reacted to the top-down advice of physicians working in the clinics. Some of the physicians' reports confirm this approach. Mothers were characterised as ignorant and lazy, unwilling to learn better breastfeeding practices and too reliant on the dangerous advice from grandmothers and aunts ${ }^{22}$.

Whether a condescending approach was widespread among physicians or an exception is hard to say. However, friendly approaches and easy access to a clinic seem to have stimulated attendance. In 1926 a female doctor succeeded Dr. Looft at the Bergen clinic and midwives were now attached to the clinic. Shortly afterwards the clinic was moved nearer to the city centre and a roomy and attractive waiting room was opened. All this stimulated attendance ${ }^{23}$. But the reduction of breastfeeding continued. This leads to the second question: why would the habit of breastfeeding weaken?

An extensive study of medical records from maternity clinics in Oslo and Bergen shows that between 1900 and 1930 the mortality of breast-fed children was much lower than for children not breast-fed ${ }^{24}$ (Table 3).

21. Urd, 1900, p.128-129; 1903, p. 394-395, 441-443 and 453; 1904, p. 544-545; 1912, p. 203. Kvinden; 1911, nr. 4, 7 and 8; 1912, nr. 5; 1916, nr. 4, 6 and 11. Blom, n. 15, p. 54-58.

22. Kjelsberg, H. Medicinsk Revue. Magazin for Lægevidenskaben; 1909: 212-213. Carl August Loft in Bergens Tidende, October 31st, 1916. Ironically, new knowledge has recently shown that at the age of 2-3 month a healthy child will usually want more food. If breast-feeding is then done more often, this will stimulate the mother's capacity to produce more milk. If not, the mother will not be able to produce the amount of milk the child needs. Consequently, during the early 20th century the strict time regime recommended by physicians, meant to assist mothers, may on the contrary have contributed to create problems for mothers who breastfed for more than 2-3 months. Lykke, Anne. Døden i barndommen. Spædbørnsdødelighed og moderniseringsprocesser i Danmark 1800 til 1920. Copenhagen: Gyldendalske Boghandel, Nordisk Forlag A/S; 1998.

23. Annual reports form the municipal Board of Health, Bergen, 1919, 1921 and 1927-30.

24. Rosenberg, Margit. Breast-feeding and infant mortality in Norway 1860-1930. Journal of Biosocial Sciences. 1989; 21: 335-348. 
Table 3. Mortality rates for the first $\mathbf{1 2}$ months for live-born infants by birth year group, breast-fed and non-breast-fed, born to married and unmarried mothers.

Norway, 1901-1930

\begin{tabular}{cccccccccccccc}
\hline & \multicolumn{4}{c}{ Lactation up to 12 months } & \multicolumn{1}{c}{ No lactation } \\
\hline & \multicolumn{1}{c}{ Total } & Married & Unmarried & Total & \multicolumn{3}{c}{ Married } & Unmarried \\
\hline Birth year group & $\%$ & $\mathrm{~N}$ & $\%$ & $\mathrm{~N}$ & $\%$ & $\mathrm{~N}$ & $\%$ & $\mathrm{~N}$ & $\%$ & $\mathrm{~N}$ & $\%$ & $\mathrm{~N}$ \\
\hline $1901-15$ & 10 & 1,657 & 8 & 1,376 & 24 & 281 & 28 & 167 & 22 & 139 & 48 & 38 \\
$1916-30$ & 4 & 1,532 & 4 & 1,443 & 2 & 89 & 18 & 79 & 16 & 71 & 26 & 8 \\
\hline
\end{tabular}

Source: Rosenberg, Margit. Breast-feeding and infant mortality in Norway 1860-1930. Journal of Biosocial Sciences. 1989; 21: 339.

No doubt then, breast-feeding was important for the survival of infants. But the same study shows that mortality rates were also strongly reduced for infants that were not breast-fed, falling from 28 to $18 \%$ during the same period. While breast-feeding continued to be important, other things must also have contributed to the reduction of infant mortality.

The home environment as well as to the public environment come into focus. Margit Rosenberg points to the routines of pasteurising milk and sterilising bottles, making bottle-feeding a safer approach. The marketing of artificial milk products, especially from Nestle, may also have stimulated the reluctance many mothers had to breastfeeding ${ }^{25}$. In this situation, complaints about the problems involved in breastfeeding may help understand why an increasing number of mothers now reduced this way of feeding their infants. In a number of women's journals women complained that husbands had no understanding for the exhausting and time consuming business of caring for a toddler, but on the contrary expected wives to continue to look young and beautiful ${ }^{26}$. Some mothers obviously did not enjoy breastfeeding. If other feeding practices were seen as equally good for infant health, they would gladly stop this annoying business. As if supporting mothers who did not like to breastfeed in 1947 the annual report

25. Annual report from the municipal Board of Health, Bergen, 1918. Rosenberg, n. 12, p. 55. Blom, n. 15, p. 51-52.

26. Blom, n. 15, p. 57 
from the Bergen municipal health authorities stated that the importance of breastfeeding for the health of a child had been overrated ${ }^{27}$.

Alternative feeding methods had made breast-feeding less decisive for infant health. This would be part of the explanation why infant mortality continued to fall even as mothers breastfed less. But safe bottle-feeding would be a lot easier to provide for mothers with some means than for the poorer mothers. As a matter of fact, regardless of whether mothers breast-fed or not, the civil status of the mother made a big difference in infant mortality (Table 3). Although this difference was somewhat reduced, it persisted during the period 1916-1930. This indicates the importance of the economic and social situation of mothers and infants. The home environment assumed importance.

This becomes obvious from the sharp reduction in the most common causes of infant deaths occurring between 1900 and 1935.

Table 4. Deaths from the most important causes, age 0 - 1 year.

Norway, 1900-1935

\begin{tabular}{lcc}
\hline & 1900 & 1935 \\
\hline Diarrhoea and intestine infections & 100 & 13 \\
Tuberculosis & 100 & 22 \\
Other infectious diseases & 100 & 25 \\
Pneumonia and influenza & 100 & 46 \\
\hline
\end{tabular}

Source: Backer, Julie E.; Aagenæs, Øystein. Dødelighet blant spedbarn i Norge 1901-1963. Infant mortality in Norway 1901-1963. Oslo: Statistisk sentralbyrå [Samfunnsøkonomiske studier; 17]; 1966, table 25, p. 47.

Reduction in infant deaths from diarrhoea and intestine infection had started already during the 1890's, and accelerated after the turn of the century. In 1935 it had fallen to almost one tenth of the 1900-level. This has been seen as the most important cause of the reduction of infant death rates ${ }^{28}$. The effects of tuberculosis and other infectious diseases were also

27. Blom, n. 15, p. 58-60 and p. 62. Annual report from the municipal Board of Health, Bergen, 1947.

28. Hubbard, n. 7, p. 31-39. 
seriously curtailed. Healthier housing and better cleanliness must have saved many infants' lives. Running water became increasingly common, electricity also assisted in making it easier to keep the home clean. Add to this that the importance of healthy food was emphasised through household economics introduced in girls' schools and through widespread information campaigns addressed at housewives. During the interwar period the question of nutrition became part of social policies ${ }^{29}$. Both the home and the public environment must have had an impact.

The effects of all this may have been strengthened by the activities of the many control clinics that grew up during the interwar period. Responding to the crises of the falling birth rates, these clinics worked to save infant lives by advising mothers to breastfeed according to a strict time table and for at least one year. They also gave advice on other problems pertaining to infant health and they offered early assistance and easy access to physicians. The fewer children born became healthier and lived longer.

But what one group saw as a crisis, another saw as a possibility. For some, the falling birth rate was the very means to obtain healthier children. A reduction in the number of children born to an average family could help solve a number of problems, among them also the care of the children already born. The abrupt fall in marital fertility rates during the interwar period indicates that this was a successful strategy. It fundamentally changed the maternal and home environment. Taking care of two or three kids must have been a lot easier than coping with four or six. This was one of the core arguments for those who opened the other kind of clinics, the 'hygienic mothers' clinics'.

29. Melby, Kari. Husmortid 1900-1950. In: Blom, Ida; Sogner, Sølvi, eds. Med kjønnsperpsektiv på norsk historie. Fra vikingtid til 2000"årsskifte. Oslo: Cappelen Akademisk Forlag; 2006 (1999), p. 257-331, especially p. 320-323. Backer, Julie E.; Aagenæs, Øystein. Dødelighet blant spedbarn i Norge 1901-1963 Infant mortality in Norway 1901-1963. Oslo: Statistisk sentralbyrå [Samfunnsøkonomiske studier; 17], 1966. Avdem, Anna Jorunn; Melby, Kari. Oppe først og sist I seng. Husarbeid I Norge fra 1850 til i dag. Oslo: Universitetsforlaget; 1985, p. 110-111, 129-133. Haavet, Inger Elisabeth. Maten på bordet, 50 år med statens ernæringsråd. Oslo, Statens ernæringsråd; 1998, p. 20-27 and p. 39-45. Blom, Ida. Vann-fra fare til forebygging. Tidskrift for kultureforskning. 2006; 5 (2): 5-20. 


\section{Hygienic mothers' clinics - (Mødrehygienekontorer)}

The term «hygienic» was a metaphor for contraception, a very controversial phenomenon and strongly tabooed during the first half of the twentieth century ${ }^{30}$.

The first of these clinics was established in Oslo in 1924 by Katti Anker Møller. She had for decades worked to improve the situation of poor mothers. She had fought for the Castberg Children's Laws, adopted in 1915 and already in 1913 she strongly criticised the draconic law that until 1960 made abortion a crime. Katti Anker Møller had a wide international network. She corresponded with German and British feminists, such as Helen Stöcker and Charlotte Perkins Gilman. In 1912 she attended the First International Eugenics Congress in London. But she did not like the way eugenicists reasoned. She did, however, meet leaders of the Malthusian League and she was attracted to their arguments because of their interest in alleviating poverty by family planning ${ }^{31}$.

Inspiration for Katti Anker Møller's clinic came from the United Kingdom. Here Mary Stopes had caused a sensation with her book «Married Love», where she recommended contraception within marriage ${ }^{32}$.

As mentioned earlier, in 1921 Møller's translation of part of a brochure written by Stopes was published with the title «A letter to working mothers on how to Have Healthy Children and Avoid Weakening Pregnancies». In 1922 Katti Anker Møller went to London to study how Stopes' clinics functioned. Two years later, cooperating with women within the Labour Party, Møller opened the first hygienic mothers' clinic in Oslo. In 1937, nineteen hygienic mothers' clinics existed, spread all over the country. A national association of hygienic mothers' clinics was founded to support and inspire the work in these clinics. The intention of the hygienic mothers' clinics was to make it possible for women to decide on their own - even

30. Where no other sources are quoted, the following builds on Blom 1980 and Blom 2007, n. 5, and Schiøtz, n. 2, p. 240-245.

31. Blom, Ida. Voluntary motherhood 1900-1930: Theories and policies of a Norwegian feminist in an international perspective. In: Bock, Gisela; Thane, Pat, eds. Maternity and gender policies. Women and the rise of the European welfare states, 1880s-1950s. London: Routledge; 1991, p. 21-39. Haavet, Inger Elisabeth, ed. Katti Anker Møller: módrenes forkjemper 125 år. Bergen: The Centre for Women's Studies in the Humanities; 1994.

32. Rose, June. Mary Stopes and the sexual revolution. London and Boston: Faber and Faber; 1991, p. 130-150. 
without consulting a husband- how many children they wanted. The hygienic mothers' clinics stressed the need for worn-out mothers to avoid another pregnancy in order to be able to take better care of the children already born. The means was to give women information on and access to contraception.

The clinics, especially the first one in Oslo, were strongly criticised. Conservative politicians and clerical people saw children as a gift from God and maintained that pregnancy should not be interfered with ${ }^{33}$. They stressed the importance of seeing sexual intercourse as something that belonged within marriage and as a means to beget children. If no children were wanted, sexual abstinence should be the solution. A law suit was filed against the activities of the Oslo clinic. The Association for the Protection of Morality (Moralvernforeningen), a voluntary organisation that for years had worked to convince prostitutes to change their lives, actively supported the accusations made. The clinic was attacked not only by conservative people, but also by influential women, such as the leader of the Housewives Association, Marie Michelet, and the first female factory inspector, Betzy Kjelsberg. But the critics were not heard. The law court in 1927 decided that it was legal to spread information on contraception ${ }^{34}$. The quality, not the quantity of the population was the main worries.

The Oslo clinic was supported by the women's organisation within the Labour Party, and from 1930 received some economic support from municipal authorities ${ }^{35}$. In other cities women within the Labour Party who pioneered hygienic mothers' clinics had to fight strong opposition. This was the case in the west-coast city of Stavanger where the clinic had to close down in 1932.

Municipal economic assistance to the hygienic mothers' clinics often depended on shifting political constellations. By and large, Liberals and Conservatives were critical and religious concerns were forwarded to hinder the use of contraception. Representatives of the Labour Party were usually friendlier to these clinics. During the early 1930's inspiration from a book on the population crises, published by the Swedish couple Gunnar and Alma Myrdal helped strengthen the arguments within the Labour Party for supporting the hygienic mothers' clinics. But the argumentation shifted from

33. Aftenposten 15h June 1926; Værn 1926, p. 86-87. Blom, n. 5, p. 181-190 and 214-222.

34. Blom, 1980, n. 5, p. 192-194. Blom, 2007, n. 5, p. 80.

35. Blom,1980, n. 5, p. 202-209. Schiøtz, n. 2, p. 240-245. 
assisting worn-out mothers to using the fall in fertility in the fight for wider social reforms that would strengthen the health of working class families. Now also younger socialist physicians started to support contraception, among them Karl Evang, the future director general of health.

Still, resistance to contraception continued to be wide-spread. In 1938, a Labour government decided to give economic support to control stations for mothers and children where no information on contraception was offered. Against an important minority in 1939 state support was extended to the hygienic mothers' clinics. But during the war all the hygienic mothers' clinics were closed by the German occupational forces. When the clinics reopened after the war confrontations over contraception resumed in Parliament. The vivid discussions on the activities of the hygienic mothers' clinics were more concerned with questions of morality than with the problem of the falling fertility. Attitudes changed slowly, and until the 1970's financial support for information on contraception had to cope with strong opposition. Finally, open information on contraception was gradually accepted ${ }^{36}$.

The importance of contraception for the sharp fall in marital fertility during the interwar period has been doubted. Since all talk of contraceptives continued to be highly tabooed, many researchers have concluded that the reduction in fertility was made possible by a combination of sexual abstinence and withdrawal, both methods depending on cooperation between spouses ${ }^{37}$.

Although the control clinics and the hygienic mothers' clinics disagreed on how best to assist mothers in their efforts to have healthier infants, both initiatives aimed at reducing infant mortality. The means were different. The control clinics gave priority to breast-feeding and better infant care, while the hygienic clinics saw a reduction of fertility as the main means to healthier infants. Lively and prolonged discussions on contraception throughout the first half of the 20th century confirm the last approach.

\footnotetext{
36. Blom, 1980, n. 5, p. 213-214.

37. Szreter, Simon. Fertility, class and gender in Britan 1860-1940. Cambridge: Cambridge University Press; 1996, p. 367-440.
} 


\section{Discussing fertility and infant health}

Discussions in middle class women's journals already at the turn of the century and in letters to the Oslo hygienic clinic during the 1920's show that the need to take better care of infants was a prominent motive for having fewer children. The journals were full of advice on better child-care and also pointed to the complicated character of modern child-care. Mothers were to rely on medical experts and warned against leaving the infant with a nurse maid. A mother should take care of the infant herself ${ }^{38}$.

It was stressed that fewer children would greatly enhance the health of mothers, and healthier mothers would provide better child-care. In letters to the hygienic mothers' clinic in Oslo working class mothers complained that a great number of children and often complications when giving birth, left them with little strength to take care of the children they already had ${ }^{39}$.

However, the wish to take better care of infants was not the only motivation for reducing fertility. Discussions started already around 1900 on why fewer children would be a benefit for the family. The need to secure a certain acceptable standard of living was important to middle class women. New demands, such as education not only for boys, but also for girls, sprang out of what was seen as an alarming growth in the rate of unmarried women, caused by emigration of young men, especially to the USA. This made it important for a middle class girl to have enough education to survive by a decent occupation if she did not marry. But private girls' schools might be as expensive as a full year's salary for a servant girl. Since a servant girl was seen as indispensable, fewer children could be the solution.

Working class mothers did not worry about the education of children. They were used to see both boys and girls attempt to fend for themselves and assist in making the family economy viable. For these mothers economic disaster caused by unemployment or the sickness of the breadwinning husband were the main worries ${ }^{40}$.

Finally, modernity seemed to result in new approaches to motherhood. Discussions in women's journals show that younger middle class women wanted more time not only for child care and cultural activities - reading

\footnotetext{
38. Urd, 1900, p. 128. Urd, 1904, p. 544 and 574.

39. Blom, 1980, n. 5, p.140-143. Blom, 2007, n. 5, p. 71-73. For an extensive analysis of these discussions, see Blom, 1980, n. 5, p. 64-155.

40. Blom, 1980, n. 5, p. 64-154. Blom, 2007, n. 5, p. 64-82, 97-106
} 
and playing the piano- but also to get involved in what happened around them ${ }^{41}$. For women within the Labour Party, reducing the number of children could be seen as a weapon in the class struggle. Fewer children would make it possible also for working class women to take part in this struggle and liberate them from economic and political dependence on men ${ }^{42}$. The importance of ideas about women's emancipation surfaces clearly in the study undertaken by Sølvi Sogner. Hege Brit Randsborg and Eli Fure. Where women were eager to use their right to vote at national elections, i.e. where women were interested in politics - in Norway women won national suffrage in 1913- marital fertility tended to fall earlier than where this was not the case ${ }^{43}$.

The hope of improving infants' health was one among a series of reasons for the wish to limit the number of children. Breast-feeding was important to infant health, but attempts to reduce infant mortality by changing women's breast-feeding habits were not always successful. Still, the work of the many 'control clinics' assisting mothers with medical advice on infant care, must have had some importance. Structural changes in society made all these efforts easier. Higher standards of living made better room for infant care ${ }^{44}$.

All in all, though giving priority to different problems, both the control clinics and the hygienic mothers' clinics must have been involved in the strong improvement of infant health starting already before the First World War and accelerating during the interwar period. In the middle of the 1930's other concerns for the health of infants were met with different measures.

\section{Sterilisation: Part of welfare policies?}

Some infants were thought to suffer from problems that could not be helped. Better infant care would help also such children survive, and it was feared

\footnotetext{
41. Nylænde, 1902, p. 135-137. Blom, 1980, n. 5, p. 121.

42. Blom, 1980, n. 5, p. 144-146. Arbeiderkvinnen January 1934

43. Sogner, Sølvi ; Randsborg, Hege Brit; Fure, Eli. Fra stua full til tobarnskull : om nedgangen i barnetall i norske familier i de siste 200 år, med særlig vekt på perioden 1890-1930. Oslo: Universitetsforlaget; 1984, p. 86-87.

44. Schiøtz, n. 2, p. 102-110.
} 
that this might lead to a degeneration of the population. To counteract this development it was seen as important to avoid births of mentally, physically or socially handicapped individuals. Sterilization might help curtail the procreative capacities of individuals thought to be hereditary bearers of such abnormalities. In this light sterilisation policies could be seen as part of social policies leading up to the welfare state ${ }^{45}$.

Ideas of possible adverse consequences of inheritance originated in Norway with the pharmacist Jon Alfred Hansen Mjøen (1860-1939). He had studied in Germany, and in 1906 he founded a private research institute for eugenics in Oslo. His message was that not only the social environment, but most of all biological inheritance and race were important for the quality of the population. Mjøen's ideas were soon met with vivid criticism. Among his opponents were medical and biological experts, such as Kristine Bonnevie, the first female professor in Norway, who headed the Institute of Genetics at the Oslo University, and Otto Lous Mohr, professor of anatomy, who had studied in the USA. He was the son in law of Katti Anker Møller and deeply interested in social questions. The main objection to Mjøen's ideas was that science had so far not been able to provide safe evidence that physical and psychic problems, such as blindness and mental deficiency, were hereditary ${ }^{46}$.

However, during the 1920's and early 1930's, sterilisation as a means to avoid a degeneration of the nation, was more widely accepted. In the heated discussions on the possibility of decriminalising abortion during the late 1920's and early 1930's abortion was also suggested as an acceptable solution where a pregnancy occurred with «less valuable individuals», as well as in cases where poverty, degeneration, alcoholism or disease made a family a burden for society 47 . This did not materialise, but a bill forwarded in the early 1930's followed the same line of thoughts. It was proposed to make sterilization dependent on a personal application to central health authorities, $(\$ 3,1)$, except in the case of the «feeble-minded» and «men-

45. Roll-Hansen, Nils. Norwegian eugenics: Sterilization as social reform. In: Broberg, Gunnar; RollHansen, Nils, eds. Eugenics and the welfare state. Sterilization policy in Denmark, Sweden, Norway and Finland. East Lansing: Michigan State University Press; 1996, p. 155-170.

46. Roll-Hansen, n. 45.

47. District physician Stian Erichsen in a proposal from the Norwegian Association of Surgeons in 1929. Physician Louise Isachsen in a proposal made at a meeting of the Norwegian Association of Medicine (Det norske medicinske Selskab) in February 1931. Blom, 1980, n. 5, p. 230-231. 
tally ill'» In such cases a guardian should agree to the application. $(\$ 3,2)$. If a person was seriously 'mentally ill' and did not understand his or her own situation a guardian, the head of the institution where the person lived or police authorities could apply for sterilisation on social and/or eugenic grounds or in order to prevent criminal activities $(\$ 4)^{48}$. The law was accepted by Parliament in 1934, with little discussion and only one negative vote. The reasoning was that social policies now started to take good care of biologically unfit individuals who might otherwise have perished. Consequently, it had become necessary to regulate the fertility of such persons. This would avoid the births of further helpless individuals and reduce public spending. The latter motive had special weight during a period of prolonged economic crisis, where social policy spending had to be seriously curtailed. In this situation sterilisation might be a means of influencing the maternal environment by preventing the birth of children considered seriously handicapped.

Even the church voiced little criticism and leading socialists accepted the procedure ${ }^{49}$. But it should be stressed that the Norwegian law on sterilisation was fundamentally different from the German law adopted the year before. There was no support for ideas of race hygiene. Only one MP, Erling Bjørnson from the Agrarian Party, argued for seeing the law in a race hygienic perspective and as a first step later to be followed by policies similar to those introduced by the German law of $1933^{50}$. He had no followers.

During the short period until 1940, women by far outnumbered men among people who were sterilised according to this law. A minority of both women and men were sterilised according to $\$ 3,1$ as a result of a personal application. In some situations, for instance after having born many children, sterilization might be an alternative to contraceptive practices and

48. Haave, Per. Tvangssterilisering i Norge. In: Rømer Christiensen, Hilde; Lundberg, Urban; Petersen, Klaus, eds. Frihed, lighed og tryghed. Velfærdspolitik i Norden. Århus: Skrifter udgivet af Jysk Selskab for Historie nr. 49, 2001, p. 141-143. See Haave, Per. Sterilisering av tatere 1934-1977. En historisk undersøkels ea lov og praktis. Oslo: Norges Forskningsråd; 2000, chapter 1 and 3 for an extensive account of the sterilisation law of 1934.

49. Evang, Karl. Rasepolitikk og Reaksjon. Oslo: Fram forlag; 1934, p. 89. Tranmæl, Martin. Arbeiderblaadet 17th February 1935. See Nilsen, Kåre B. Det norske arbeiderparti og befolkningsspørsmålet i mellomkrigstiden. Unprinted master thesis (Bergen, 1978), on social-democratic population policies during the interwar period.

50. Roll-Hansen, n. 45, p. 174-175. Haave, 2001, n. 48, p. 145. 
to abortion. It should also be mentioned that sterilization performed when a pregnancy would seriously endanger a woman's life was not regulated by law. There is reason to believe that many more women were sterilized on this medical indication than according to the law of $1934^{51}$.

Table 5. Persons sterilized according to the law of 1934, 1934-1938

\begin{tabular}{|c|c|c|c|c|c|c|c|c|}
\hline \multirow[b]{2}{*}{ Year } & \multicolumn{2}{|c|}{$\begin{array}{c}\$ 3, \text { part } 1 . \\
\text { Personal } \\
\text { application }\end{array}$} & \multicolumn{2}{|c|}{$\begin{array}{l}\text { \$3, part } 2 . \\
\text { Agreed by } \\
\text { guardian }\end{array}$} & \multicolumn{2}{|c|}{$\begin{array}{l}\text { \$4. Application made by } \\
\text { guardian, head of institu- } \\
\text { tion or police authorities }\end{array}$} & \multicolumn{2}{|c|}{ Total } \\
\hline & W & M & W & M & W & M & W & M \\
\hline $1934-36$ & 8 & 8 & 12 & 10 & 28 & 1 & 48 & 19 \\
\hline 1937-39 & 36 & 22 & 54 & 6 & 103 & 17 & 193 & 45 \\
\hline Sum & 44 & 30 & 66 & 16 & 131 & 18 & 241 & 64 \\
\hline
\end{tabular}

Source: Haave, Per. Tvangssterilisering i Norge. In: Rømer Christnesen, Hilde; Lundberg, Urban; Petersen, Klaus, eds. Frihed, lighed og tryghed. Velfærdspolitik i Norden. Århus: Skrifter udgivet af Jysk Selskab for Historie nr. 49; 2001, p. 143.

Most of the sterilisations following the law of 1934 were made according to $\$ 3,2$ and $\$ 4$ that concerned people deemed «feeble-minded» or «seriously mentally ill» ${ }^{52}$. But is should not be forgotten that the categorisation of individuals according to the law would often have been a matter of opinion. A study of the practices of a similar law in Denmark indicates that what could formally be seen as a personal application or an application agreed to by a guardian, might in reality have been the result of constraining policies towards the person in question ${ }^{53}$.

Norwegian politicians showed a strong reluctance to use coercion in the question of sterilization. But in some cases sterilization was presented as a precondition for being allowed an abortion. This procedure would prevent repeated requests of abortion. Such coercion was mainly applied to women in families with social and economic problems and has also been explained by the reluctance of some of the control clinics to spread information on contraception ${ }^{54}$.

51. Haave, 2001, n. 48, p. 134-144.

52. Haave, 2001, n. 48, p. 141-142.

53. Koch, Lene. Tvangssteriisation i Danmark 1929-67. In: Rømer Christensen, n. 48, pp. 172-174.

54. Haave, 2001, n. 48, p. 150-157. 
The practice of the law on sterilization until the Second World War revealed the intention of avoiding the birth of seriously disabled children or of seeing children born into a family where proper child care could not be expected. The motive was also to avoid what was seen as excessive costs for society to secure the welfare of such children. But it has been emphasised that this policy was not part of welfare policies. On the contrary, it was a result of failures in welfare policies directed at women. Since they were not offered sufficient access to contraception and since abortion was a criminal offence, sterilization might seem the only alternative for a woman who did not feel able to take proper care of her infants ${ }^{55}$. In this light sterilisation could be understood as a last resort to influence the maternal and home environment by preventing the birth of disabled children as well as the existence of disabled parents.

\section{Conclusion}

The decline in fertility that started around 1900 and accelerated drastically during the interwar period was seen as a serious national crisis. Improving the health of the fewer children born was an important response to this situation. Norwegian national legislation in various ways aimed at assisting mothers in this task. The Medical profession and voluntary organisations staged two different kinds of clinics as part of policies to improve infant health. The control stations, started already before the First World War, but proliferating during the 1920's and 1930's, were established to assist mothers in breastfeeding and other child care measures. The hygienic mothers' clinics recommended the reduction of births as a means to make it possible for mothers to take better care of the fewer children born. A last resort in order to prevent the birth of mentally or physically handicapped children was introduced by the law on sterilisation.

It seems sensible to say that sterilization, introduced only in the middle of the 1930's and targeting only few individuals would have had very limited effect on infant health. The two other approaches, the control stations and the hygienic mothers' clinics, had more importance. True, the reduction in the frequency of breastfeeding from 1920 indicates that not all mothers

55. Haave, 2001, n. 48, p. 158-159. 
followed the advice offered at the many control stations. But other efforts of these clinics assisted mothers in rearing healthy children and must have contributed to better infant health. Paradoxically, the very reduction of the number of babies born also seems to have contributed to better infant health by improving the capacity of mothers to take care of their children. What was perceived as a crisis, the continued fall in marital fertility, proved to be one of a number of means to improve infant health.

It would, however, come as no surprise if the conclusion drawn be that policies aiming at the home environment as well as at the public environment were of great importance. Efforts to improve infant health were made more successful by rising living standards, better housing and easier access to clean water as well as a heightened understanding of cleanliness. These improvements were class related factors that would make infant care much easier for mothers of the middle class than for mothers with less economic means. Only by the advent of the welfare state after the Second World War would it be possible to seriously reduce such differences. 